\title{
JAMUN AN UNDER-EXPLOITED INDIGENOUS FRUIT TREE OF INDIA: A REVIEW
}

\author{
RS Tomar ${ }^{1 *}$, Ranjit Pal ${ }^{1}$, Prabha Singh ${ }^{2}$, Sushma Tiwari ${ }^{3}$, Amolkumar U. Solanke, \\ Mohd Tasleem ${ }^{4}$, Ashutosh Singh ${ }^{1}$, Pratibha Pandey ${ }^{5}$ and AK Pandey ${ }^{1}$ \\ ${ }^{1}$ College of Horticulture \& Forestry, Rani Lakshmi Bai Central Agricultural University, Jhansi-284003, U.P. \\ ${ }^{2}$ ICAR-IGFRI, Jhansi-284003, U.P. \\ ${ }^{, 4}$ Plant Molecular Biology and Biotechnology \\ Rajmata Vijaya Raje Scindia Krishi Vishwavidyala, Gwalior-474005, M.P. \\ ${ }^{4}$ ICAR-NIPB, Pusa Campus, New Delhi-110012 \\ ${ }^{5}$ Mahatma Gandhi Chitrakoot Gramodaya Vishwavidyalay, Chitrakoot, Satna-485334, M.P.
}

\begin{abstract}
Jamun (Eugenia jambolana or Syzygium cuminii Skeels) is an important, large, evergreen beautiful tree of the myrtaceae family. Jamun is commonly known as java plum, black plum, jambul and Indian blackberry. It is widely consumed as fresh fruit which has considerable good nutritive value. It has high therapeutic and pharmacological properties because of constituent like tannins, alkaloids, steroids, flavonoids, terpenoids, fattyacids, phenols, minerals, carbohydrates and vitamins. The tests on animals have proved for hypoglycaemic, diuretics, analgesic, antiinflammatory, antiplaque, antimicrobial, antidiarrhoel, antioxidant, gastro-protective and astringency. However, the pharmacological trials using seeds of Syzygium cuminii have been reported in the previous studies but other parts of the tree also have good potential which need to be explored. Jamun fruit is good source of iron along with minerals, sugars and other phytochemicals. The fruits have sub-acid spicy flavour and commonly used as dessert. Apart from eating as fresh, it can also be used for the preparation of delicious beverages, jelly, jam, squash, wine, vinegar and pickles.
\end{abstract}

Keywords: Jamun, ISSR Markers, Genetic Diversity, Genotypes.

\section{INTRODUCTION}

India has vast variation in soil texture and quality viz, alkaline, saline acidic, alluvial, black and red, variations in weather conditions viz., temperature, humidity and altitude and growth conditions. Depending upon all these characters it has been divided into several ecological regions. These are responsible for its rich genetic diversity in fruit crops, resulting in good amount of divergence at different centers in respect to perennial fruit crops viz., mango, citrus, grapes, guava, banana, aonla, bael, litchi, jamun, several underutilized and temperate fruits for crop improvement. This effort has over the years resulted in development of some trait-specific varieties, which are gradually entering into the production system across the country and paving the way for heralding 'Golden Revolution'. The fruit of jamun is good source of iron along with minerals, sugars and other phytochemicals (Singh et al., 1967). It also have sub-acid spicy flavour and commonly used as dessert. Apart from eating as fresh, it can also be used for the preparation of delicious beverages, jelly, jam, squash, wine, vinegar and pickles (Ochse et al., 1961).

Jamun fruit was originated from Indonesia and India which rapidly spread in Southern Asia (Periyathambi, 2007). It is widely grown in various parts of the country from extreme North to South and East to West (Table 1).

*Corresponding author: rsstomar@rediffmail.cm 
Table 1: Dispensation of Jamun species in the country.

\begin{tabular}{|l|l|l|}
\hline S.No. & Species & Distribution \\
\hline 1. & S. aquem & Assam and Meghalaya \\
\hline 2. & S. amottlanum & Western Ghats, The Nilgris, Palani and Anamalai hills \\
\hline 3. & S. aromaticum & Tamil Nadu and Kerala \\
\hline 4. & S. claviflorum & The Andamans \\
\hline 5. & S. fruticosum & Indo-Gangetic plains in the North to Tamil Nadu in the South \\
\hline 6. & S. jambos & $\begin{array}{l}\text { Many parts of India such as Assam, Bihar, Andhra Pradesh, Tamil Nadu, } \\
\text { West Bengal, coastal areas of Maharashtra and Gujarat }\end{array}$ \\
\hline 7. & S. mappaceum & Assam, Meghalaya, Arunachal Pradesh and Tamil Nadu \\
\hline 8. & S. samarangense & The Andamans and many parts of India \\
\hline 9. & S. zeylanicum & Maharastra, Karnataka, Orissa, Kerala and Andamans \\
\hline 10. & S. javanica & South India and West Bengal \\
\hline 11. & S. zeylanicum & Western Ghats of India \\
\hline 12. & Syzygium cuminii & Southeast Asia and the Pacific Islands \\
\hline 13. & Syzygium uniflora & South India \\
\hline
\end{tabular}

\section{Genetic diversity}

Jamun tree exhibits diversity in respect of vegetative growth, aspects of spread, leaf shape and fruiting habit and maturity (June - August) (Image 1). A very little work has been carried out to understand and exploit the genetic resources of jamun. Due to intensive agricultural practices and modernization the crop is fronting severe threat of genetic. The diverse and wild germplasm of Syzygium spp. is of specific value in search for derivation of resistance to races/pathotypes of fungi, bacteria, viruses and nematodes besides winter hardiness and resistance abiotic stress conditions such as drought and salinity. A number of seedling strains with considerable variation available in respect of fruit shape, size, pulp colour, total soluble sugars, acidity and earliness particularly in the region of Uttar Pradesh, Gujarat and Maharashtra offer good scope for selection of better varieties. In the very early period, Percy and Bose (1965) noted that $F_{1}$ hybrid from a cross between the Alba variety of water apple (S.javanicum) and rose apple (S. jambos) had prolific bearing with large fruits than those of the parents. The fruits contained fragrance and sweetness of rose apple. However, the majority of jamun trees available in India are of seedling origin. Owing to cross-pollination and seed propagation, there is enormous variability in respect of fruit morphology, fruit quality, maturity and productivity. The explorations carried out in the eastern Uttar Pradesh, resulted variability in respect of fruit shape (round, oval, oblong, perform), fruit base (flat, necked), fruit apex (flat, pointed), skin colour (deep purple, purple- pink, bluish-black, black), flesh colour (purple, purple-pink, white), fruit weight (5.77 - $19.73 \mathrm{~g})$, fruit length $(2.06$ - $3.81 \mathrm{~cm})$, fruit diameter $(1.94-2.98 \mathrm{~cm})$, seed weight $(0.141-1.94 \mathrm{~g})$, seed length $(1.6-2.4 \mathrm{~cm})$, seed diameter $(0.8-1.3 \mathrm{~cm})$, pulp content $(54.29-85.71 \%)$, TSS (4.5 - 17 0Brix), acidity (0.524 - $0.832 \%)$, pulp: seed ratio (3.03 - 46.38), moisture (84.5 - $86.4 \%)$, total sugars (5.32 - $11.10 \%)$ which need to be characterized for utilization in crop improvement (Anon., 2007). The study by Ashraf et al., (1987) revealed that fruit shape varied from round to oblong and apex of fruits from flat to pointed. They also observed great variability in physico-chemical characteristic of fruits, offering possibility of selecting varieties suitable for fresh market and processing. The small seed size and high pulp content with better chemical parameters are considered ideal. Singh et al. (1999) evaluated eight accessions of jamun under Faizabad conditions and reported that oblong types had more fruit weight with relatively lesser seed weight. Surveys undertaken in Karnataka to investigate the nature and extent of variability present in seedling progenies indicated good variability in respect of plant girth, leaf area, petiole length and leaf length to petiole length ratio (Prabhuraj et al., 2002). A survey in north Goa reported a wide range variation in fruit weight (3.42 - 13.67 g), length (3.31 - 5.26 $\mathrm{cm})$, girth (5.21- $9.82 \mathrm{~cm})$, pulp (58.57 - $84.55 \%)$, TSS (12.00 -26.8 0Brix), titratable acidity (0.59 - $1.63 \%)$, total sugars (6.87 - $25.31 \%$ ) and sugar: acid ratio (15.39 - 27.92) (Devi et al., 2002). 
The seed of Jamun as well as bark have several applications in Ayurveda, Unani and Chinese systems of medicine. The seed contain traces of calcium along with rich in protein and carbohydrates and widely used as cattle feed, a medicine against hyperglycemic conditions and antidote in soft-food poisoning. The fruit is a good source of carbohydrates, protein, vitamins, anthocyanins, pectin, minerals and tannins (Table 2).

Table 2: Jamun fruits nutritive value and content value.

\begin{tabular}{|c|c|c|}
\hline S. No. & Essential nutrients & Quantity (per $100 \mathrm{~g}$ of edible portion) \\
\hline 1. & Moisture (\%) & $83.7-86.4$ \\
\hline 2. & Energy (kcal) & $62-39$ \\
\hline 3. & Acidity (\%) & $0.524-0.772$ \\
\hline 4. & Total sugar (\%) & $8.41-10.68$ \\
\hline 5. & Reducing sugar (\%) & $8.40-9.85$ \\
\hline 6. & Protein (\%) & $0.53-0.65$ \\
\hline 7. & Carbohydrates (\%) & 14.0 \\
\hline 8. & Fat $(\%)$ & 0.15 \\
\hline 9. & Crude Fiber (\%) & $0.6-1.2$ \\
\hline 10. & Mineral matter (\%) & 0.4 \\
\hline 11. & Pectin (\%) & $2.3-3.7$ \\
\hline 12. & TSS (\%) & $9.0-17.4$ \\
\hline 13. & Anthocynins (mg/100g) & 115.38- 210.76 \\
\hline 14. & Tannins (mg/100g) & $201.50-386.25$ \\
\hline 15. & Antioxidant value (FRAP mg AEAC/g) & $112.38-907.75$ \\
\hline 16. & Flavonoid (mg/g) & $0.50-1.54$ \\
\hline 17. & Carotenoid (mg /100g) & $12.38-22.34$ \\
\hline 18. & Vitamin C (mg/100g) & $10.70-29.52$ \\
\hline 19. & Amino acids (mg/100g) & $7.2-9.0$ \\
\hline 20. & Vitamin A (IU) & $73-100 \mathrm{IU}$ \\
\hline 21. & Thiamine (mg) & $0.008-0.03$ \\
\hline 22. & Riboflavin(mg) & $0.009-0.01$ \\
\hline 23. & Niacin (mg) & $0.2-0.29$ \\
\hline 24. & Calcium (mg) & $8.3-15$ \\
\hline 25. & Iron (mg) & $0.8-1.2$ \\
\hline 26. & Magnesium (mg) & 4- 35 \\
\hline 27. & Phosphorus (mg) & $15-30$ \\
\hline 28. & Sodium (mg) & $26.2-34.1$ \\
\hline 29. & Potassium (mg) & $55-50$ \\
\hline 30. & Copper (mg) & $0.23 \mathrm{mg}$ \\
\hline 31. & Sulfur (mg) & $13 \mathrm{mg}$ \\
\hline
\end{tabular}

Source: Bose et al., 2001 and Anon, 2008 

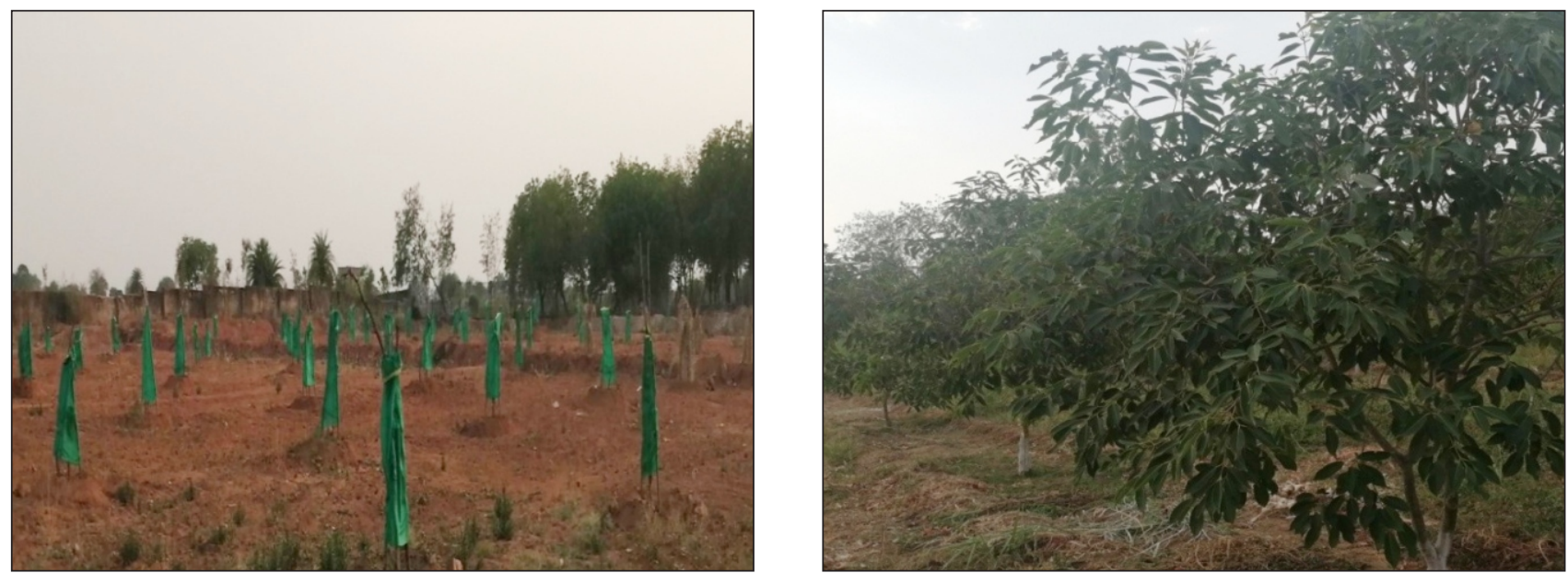

Image 1: Established orchard of jamun at Fruit Cafeteria and Block (E-18, 8) Simardha Area, RLBCAU Campus, Jhansi, Uttar Pradesh.

\section{Genetic improvement:}

To raise the productivity and quality genetic improvement is needed for higher productivity and quality of fruits in terms of edible portion, colour, shape, taste and flavour. Since, jamun is predominantly raised through seeds, wide variability prevails in seedling populations in different regions resulting into non-availability of recognized cultivars. Different types are found growing with considerable variations in respect of bearing habit, size, shape of fruits, and quality. This provides ample scope for clonal selection, which can form the immediate basis for crop improvement. Two such promising selections viz. CISH J - 37 and CISH J - 42 (seedless) have been developed by Central Institute for Sub-tropical Horticulture, Lucknow.

Advances in plant molecular biology and biotechnology which includes micropropagation, somatic embryogenesis and association mapping have been extensively used in exploiting of desirable traits. The two techniques micropropagation and somatic embryogenesis depend on cell and tissue culture (Raghavendar et al., 2019). The marker assisted selection or marker aided selection (MAS) offer precise application to make crosses in order to introgress targeted characters into existing heterozygosity. It can lead to construct genetic linkage maps of Syzygium for additional improvement. Molecular characterization of available germplasm in jamun by using multilocus marker system, ISSR is a good approach as there is dearth of sequence information (Araújo et al., 2016; Shakya et al., 2010). It will lead to analyse genetic relatedness of the selected jamun accessions. The molecular techniques can differentiate germplasm lines based on similarity and dissimilarity and their geographical origin.

\section{REFERENCES}

1. Anonymous (2008). National Network Project on Underutilized Fruits. Annual Progress Report. Central Institute for Subtropical Horticulture, Lucknow.

2. Araújo F. S., Pacheco M.V., Vieira F. A., Ferrari C. S. , Félix F. C., Chagas K. P. T. (2016). ISSR molecular markers for the study of the genetic diversity of Mimosa caesalpiniaefolia Benth. IDESIA (Chile) 34(3):47-52.

3. Ashraf, S.M. (1987). Studies on post-harvest technology of jamun fruits. Ph. D. thesis, Department of Horticulture, NDUA\&T, Faizabad.

4. Bose, T.K., S. K. Mitra and D. Sanyal (2001). Fruits: Tropical and Subtropical. Vol. II, NayaUdyog, Calcutta, India. pp. 643-56.

5. Devi, S.P., M. Thangam, A.R. Desai, and P.G. Adsule (2002). Studies on variability in physicochemical characters of different jamun (Syzygium cuminii Skeels) accessions from Goa. Indian J. Hort., 59(2): 153-156.

6. Grativol C., Lira-Medeiros C. F., Hemerly A. S.,Ferreira P.C.G. (2014). High efficiency and reliability of inter-simple sequence repeats (ISSR) markers for evaluation of genetic diversity in Brazilian cultivated Jatropha curcas L. accessions. Mol Biol Rep doi 10.1007/s11033-010-0547-7

7. Ochse, J.J., M.J. Soule, M.J.Jr. Dij Kman and C. Wehlberg (1961). Tropical and Subtropical, Agricultue, Mac. Millan, New York.

8. Periyathambi, R. (2007). Jamun - The Potential Untapped. Kerala Callin, (February), pp 30- 32. 
9. Percy L.S. and T. K. Bose (1965). IBA and NAA of 1000 ppm induce more improved rooting characters in air-layers of waterapple (Syzygium javanica l.) Bulg. J. Agric. Sci., 15:123-128.

10. Prabhuraj, H.S., G.S.K. Swamy, S.I. Athani, B.R. Patil, N.C. Hulamani and P. B. Patil (2002). Variability in morphological characteristics of jamun (Syzygium cuminii Skeels) trees. My Forest, 38 (2): 187-189.

11. Raghavendar G., Khannam A. and Rathore T. S. (2019). An efficient protocol for in vitro propagation of mimosa pudica l., - a medicinally important plant species. Inter Agric Sci. 10 (1 \& 2): 29-33.

12. Shakya R., Siddiqui S. A., Srivatawa N., and Bajpai A. (2010). Molecular characterization of jamun (Syzygium cumini l. Skeels) genetic resources. Inter. Fruit Sci., 10:29-39, 2010.

13. Singh, I.S., A.K. Srivastava and V. Singh (1999). Improvement of some underutilised fruits through selection. J. Appl. Hort., 1 (1): 34-37.

14. Singh, S.K., S. Krishinamurthy and S.L. Katyal (1967). Fruits culture in India, ICAR, New Delhi. 